\title{
EIL2 Transcription Factor and Glutathione Synthetase Are Required for Defense of Tobacco Against Tobacco Blue Mold
}

\author{
Orlando Borrás-Hidalgo, ${ }^{1}$ Bart P. H. J. Thomma, ${ }^{2}$ Cyrelys Collazo, ${ }^{1}$ Osmany Chacón, ${ }^{3}$ \\ Carlos J. Borroto, ${ }^{1}$ Camilo Ayra, ${ }^{1}$ Roxana Portieles,, ${ }^{1}$ Yunior López, ${ }^{1}$ and Merardo Pujol ${ }^{1}$ \\ ${ }^{1}$ Laboratory of Plant Functional Genomics, Center for Genetic Engineering and Biotechnology, P.O. Box 6162, \\ Havana, 10600, Cuba; ' 2 Laboratory of Phytopathology, Wageningen University, Binnenhaven 5, 6709 PD Wageningen, \\ The Netherlands; ${ }^{3}$ Tobacco Research Institute, Carretera de Tumbadero Km. 8, P.O. Box 6063, \\ San Antonio de los Baños, Havana, Cuba
}

Submitted 6 September 2005. Accepted 28 November 2005.

In order to identify tobacco (Nicotiana megalosiphon) genes involved in broad-spectrum resistance to tobacco blue mold (Peronospora hyoscyami f. sp. tabacina), suppression subtractive hybridization was used to generate cDNA from transcripts that are differentially expressed during an incompatible interaction. After differential screening by membrane-based hybridization, clones corresponding to 182 differentially expressed genes were selected, sequenced, and analyzed. The cDNA collection comprised a broad repertoire of genes associated with various processes. Northern blot analysis of a subset of these genes confirmed the differential expression patterns between the compatible and incompatible interaction. Subsequent virus-induced gene silencing (VIGS) of four genes that were found to be differentially induced was pursued. While VIGS of a lipid transfer protein gene or a glutamate decarboxylase gene in Nicotiana megalosiphon did not affect blue mold resistance, silencing of an EIL2 transcription factor gene and a glutathione synthetase gene was found to compromise the resistance of Nicotiana megalosiphon to P. hyoscyami f. sp. tabacina. Potentially, these genes can be used to engineer resistance in blue mold-susceptible tobacco cultivars.

Additional keyword: ethylene.

Tobacco is a seasonal crop that is grown in many temperate, warm and cool, humid farming zones worldwide. Historically, one of the most destructive diseases of tobacco in growing areas all around the world has been downy mildew, or blue mold, responsible for losses of hundreds of millions of dollars (Heist et al. 2002; Johnson 1989). The pathogen responsible for tobacco blue mold is Peronospora hyoscyami de Bary f. sp. tabacina, an obligate biotroph for which species from the genus Nicotiana are the only hosts. The pathogen typically causes localized

Corresponding author: O. Borrás-Hidalgo; Telephone: +(53-7) 271 6022; Fax: +(53-7) 33 1779; E-mail: orlando.borras@ cigb.edu.cu

Nucleotide sequence data is available from the GenBank database under accession numbers DV270764 to DV270779 and DV668283 to DV668448.

* The $\boldsymbol{e}$-Xtra logo stands for "electronic extra" and indicates the HTML abstract available on-line contains a supplemental figure not included in the print edition. lesions on the leaves that appear as single or groups of yellow spots that often coalesce to form light brown necrotic areas (Lucas 1975; Wolf et al. 1934). Under favorable conditions, the pathogen can destroy complete leaves. In addition, the pathogen can enter the vascular system and thus spread systemically throughout the plant (Lucas 1975; Reuveni et al. 1986). This can lead to stunting of plants or even lodging if the base of the stem is affected. Blue mold infection of a field crop is initially observed as circular, yellow areas of diseased seedlings. Plants in the center of the affected area may have cupped leaves. The upper surfaces of infected leaves can remain almost normal in appearance until the plants begin to die and their color turns light brown. Some of the leaves exhibit gray-bluish downy mold on their lower surface. Diseased leaves can become so twisted that the lower surfaces turn upward. In such cases, the bluish color of the diseased plants becomes quite conspicuous, especially under moist conditions when sporulation is abundant.

Several defense responses have been reported to occur in the Nicotiana tabacum-Peronospora hyoscyami interaction (Avdiushko et al. 1993; Funnell et al. 2004; Pan et al. 1991; Ye et al. 1989, 1990). These include activation of pathogenesisrelated (PR) genes and increases in the activities of typical PR proteins, such as peroxidases, chitinases, $\beta$-1-3-glucanases, and lipoxygenases. Systemic acquired resistance (SAR) is one of the best-characterized tobacco defense responses that are activated upon pathogen infection. SAR is activated when pathogens induce localized plant necrosis during an initial infection and leads to long-lasting and broad-spectrum enhanced resistance against virulent and avirulent tobacco pathogens (Kuc 1982). Funnell and associates (2004) showed that upregulation of the $P R-2$ gene, $P R-2 d$, following stem inoculation with $P$. hyoscyami is associated with SAR. Studies using plants transformed with $\beta$-glucuronidase constructs containing the full-length promoter from $P R-2 d$ or promoter deletions provided evidence that a previously characterized regulatory element that is involved in response to salicylic acid (SA) may be involved in regulation of $P R-2 d$ following induction of SAR with $P$. hyoscyami. This work provides evidence that regulation of $P R-2$ genes during $P$. hyoscyami-induced SAR may be similar to regulation of these genes during infection of $\mathrm{N}$-gene tobacco by Tobacco mosaic virus or following exogenous application of SA and provides further support for the role of SA in regulation of genes during $P$. hyoscyami-induced SAR. 
Resistance to blue mold in species of the genus Nicotiana varies from highly susceptible to immune (Clayton 1945). Among the highly susceptible species is commercially cultivated tobacco (N. tabacum). In the late 1970s, the systemic fungicide metalaxyl was used in many tobacco-growing areas to control $P$. hyoscyami, which led to the emergence of resistant pathogen strains (Johnson 1989). The noncultivated tobacco species Nicotiana megalosiphon has been shown to be highly resistant to Peronospora hyoscyami (Espino and Rey 1987). Therefore, this species is used as a parent in genetic crossing programs of the Cuban Tobacco Research Institute, aimed at obtaining disease-resistant tobacco cultivars that can be commercially exploited (Espino et al. 1997). To gain insight into the molecular components that are responsible for the establishment of the resistance of $N$. megalosiphon to tobacco blue mold, a suppression subtractive hybridization (SSH) approach was used to generate a cDNA library containing transcript-derived fragments from $N$. megalosiphon genes that are induced during interaction with $P$. hyoscyami. Subsequently, employing virus-induced gene silencing (VIGS) in $N$. megalosiphon, the contribution of a number of genes to actual disease resistance was evaluated. These experiments have demonstrated that silencing of two genes, encoding a glutathione synthetase and an EIL2 transcription factor, respectively, compromised $P$. hyoscyami resistance in N. megalosiphon.

\section{RESULTS}

Construction of the subtracted cDNA library.

In order to obtain a comprehensive set of genes that are induced in the $P$. hyoscyami-resistant tobacco species $N$. megalosiphon, a subtracted cDNA library was made. Leaf material was collected from infected $N$. megalosiphon plants at 2, 4, and 6 days after inoculation and was pooled before RNA extraction. This material was used to generate the tester sample. For the driver sample, plant material from mock-inoculated plants harvested at the same timepoints was used. After subtractive hybridization, a cDNA library was obtained containing $P$. hyoscyami-induced N. megalosiphon genes.

To validate the quality of the subtracted library and to further select its content, clones were randomly picked and spotted on membranes, which were subsequently hybridized using labeled driver cDNA, labeled tester cDNA, and labeled forwardsubtracted cDNA as probes. The hybridization using the driver cDNA provides information on the efficiency of the subtraction, as this hybridization should not result in any signal if the subtraction fully succeeded. In addition, with the hybridization using the tester cDNA, the most abundantly expressed differentials can be identified, while the hybridization using the subtracted cDNA reveals less abundantly expressed differentials. The clones showing the most pronounced differential expression pattern were selected for sequencing. In this way, 258 clones were screened, and 182 of them were retained for sequencing.

\section{Sequence analysis.}

All 182 differentially expressed clones were sequenced. BLASTX and BLASTN homology searches (Altschul et al. $1997)$ were performed for all sequences and $E$-value scores below $10^{-5}$ were considered as statistically significant. Over $24 \%$ of the sequenced clones did not result in a significant hit and were, therefore, classified as being of unknown function. The genes for which a significant hit was found were sorted into six primary functional categories as shown in Figure 1. The largest set of these genes (20\%) was assigned to metabolism, while genes involved in protein synthesis constituted the smallest group, comprising less than $8 \%$ of the sequences. Genes involved in defense formed the second largest group (16\%). Genes implicated in signal transduction and in energy and transport constituted 12 and $10 \%$ of the cDNA collection, respecttively (Fig. 1).

\section{Expression analysis.}

Based on the homology displayed with sequences in public databases, 16 genes with a significant hit in the BLAST analysis were selected (Table 1) and their expression was analyzed. To this end, Northern blots were prepared with total RNA extracted from resistant ( $N$. megalosiphon) and susceptible ( $N$. tabacum cv. Sumatra) plants at 2, 4, and 6 days after $P$. hyoscyami inoculation. Through Southern blot analysis, it was verified that the probes for all $16 \mathrm{~N}$. megalosiphon genes equally hybridize to their $N$. tabacum homologs. Northern blot analysis indicated that the expression levels of the transcripts for the 16 genes was generally very high in the incompatible interaction as compared

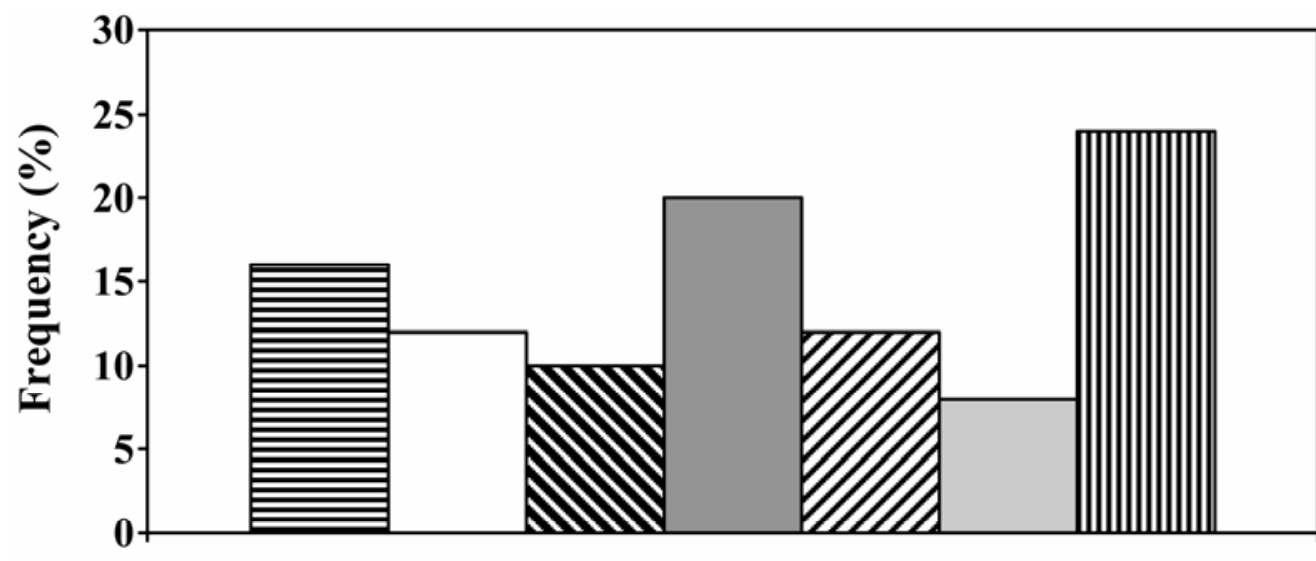

\begin{tabular}{|lll}
\hline 目Defense & $\square$ Signal transduction $\mathbf{D}$ Transport \\
$\square$ Metabolism & $\square$ Energy & $\square$ Protein synthesis \\
س Unknown function & & \\
\hline
\end{tabular}

Fig. 1. Classification of the total pool of identified suppression subtractive hybridization clones according to their putative functions. All 182 differentially expressed clones were included, regardless of $E$-values or number of individual copies. 
with expression levels in the compatible interaction, for which transcript levels were either very low or undetectable (Fig. 2). Similar expression levels were found in both interactions at the same timepoints only for one clone, homologous to an ethylene receptor-like protein gene (GBII57). Some transcripts (GBII25, GBII49, GBII52, GBII57, and GBII77) were found to be induced in both interactions, but expression was either later or lower in the compatible interaction (Fig. 2). Clones whose sequence displayed homology with genes encoding a lipid transfer protein (LTP, GBII10), a glutathione synthetase (GSHS, GBII38), an EIL2 transcription factor (EIL2, GBII42), an alcohol dehydrogenase-like protein ( $A D L$, GBII77), and a glutamate decarboxylase ( $G D$, GBII85) exhibited strong induction at all timepoints evaluated in the incompatible interaction. All of these, except the $A D L$ gene, were found not to be induced at all in the compatible interaction.

Because of their quick and strong induction in the incompatible interaction and the absence of their induction in the compatible interaction, it was anticipated that the clones encoding the LTP (GBII10), GSHS (GBII38), EIL2 transcription factor (GBII42), and GD (GBII85) might be the most likely prospective candidates to evaluate for their contribution to the diseaseresistance phenotype of $N$. megalosiphon. Reverse transcription-polymerase chain reaction (RT-PCR) analysis was carried out to assess the regulation of their transcripts in N. megalosiphon plants upon ethylene, salicylic acid, or jasmonic acid treatment, as these molecules are well-known for their role in modulating plant defense responses upon pathogen attack (Thomma et al. 2001). While transcripts of the EIL2 transcription factor (GBII42) were induced upon treatment with ethylene but not with either jasmonic acid or salicylic acid, the LTP transcripts (GBII10) were found expressed solely upon treatment with jasmonic acid. The GSHS (GBII38) and GD (GBII85) genes were not activated upon treatment with ethylene, salicylic acid, or jasmonic acid (Fig. 3).

\section{Functional analysis of selected genes.}

To test whether the clones encoding the LTP (GBII10), the GSHS (GBII38), EIL2 transcription factor (GBII42), and GD (GBII85) genes indeed contribute to the disease-resistant phenotype of $N$. megalosiphon, it was attempted to knock down their induction in N. megalosiphon using VIGS. To this end, constructs were designed and inoculated on N. megalosiphon plants. Silencing of phytoene desaturase (PDS; Fray and Grierson 1993) was used as a control. The $P D S$ gene can easily be used to demonstrate the efficiency of VIGS. The PDS gene is involved in the carotenoid metabolic pathway, acting on the antenna complex of thylakoid membranes, and its product pro- tects the chlorophyll from photooxidation. Silencing of the $P D S$ gene results in a drastic decrease in leaf carotene content, leading to macroscopically visible bleaching of green tissues.

Inoculation with the tobacco rattle virus (TRV)-based constructs containing a $P D S$ fragment resulted in extensive bleaching that covered all parts of a leaf's lamina and spread systemically toward younger tissues of the inoculated leaf. However, this was not observed in all the plants evaluated. About half of the plants evaluated did not show VIGS, which demonstrated that the TRV system was not fully efficient to produce silenced N. megalosiphon plants (Table 2). This was confirmed by subsequent Northern analysis to monitor the expression of the four genes encoding LTP (GBII10), GSHS (GBII38), EIL2 transcription factor (GBII42), and GD (GBII85), as only one-third to half of the plants showed significantly lowered transcript levels (Table 2). Therefore, after disease susceptibility testing, plants were tested for transcript levels by Northern blotting (Fig. 4), and only those plants showing significantly lowered transcript levels were taken into account. For these plants, it was shown that silencing of the GBII42 and GBII38 transcripts, for the GSHS- and the EIL2 transcription factor-encoding genes, respectively, compromised the resistance to P. hyoscyami (Fig. $5)$, which demonstrates that the function of these genes is required for resistance to $P$. hyoscyami. However, the disease symptoms were less severe than in the susceptible control (Table 3). Silencing of the GBII10 and GBII85 transcripts (LTP and $G D$, respectively) did not compromise resistance to $P$. hyoscyami (Fig. 5).

\section{DISCUSSION}

In this study, cDNA subtractive hybridization was used to specifically isolate cDNA sequences that are differentially expressed upon inoculation of tobacco blue mold-resistant $N$. megalosiphon with $P$. hyoscyami. Random screening of clones from the subtracted library of the incompatible interaction using serial hybridization analysis on cDNA macroarrays resulted in successful detection of transcripts that are preferentially expressed. In this way, 182 cDNAs were identified that are differentially regulated in the incompatible interaction. Database searches demonstrated that many of the differentially expressed tobacco cDNAs show homology to known genes, some of which have previously been implicated in disease resistance (Table 1). Although functional assignment based only on sequence homology needs experimental verification, it nonetheless provides a clue regarding the diversity of the genes that are induced.

Clones with the highest $E$-values were selected and were, indeed, shown to display differential expression patterns in the

Table 1. Summary of identified suppression subtractive hybridization clones and their BLAST search results

\begin{tabular}{|c|c|c|c|c|c|}
\hline Clone & Accession number & GenBank hit & BLASTN * / BLASTX sequence homology & Identity (\%) & $E$-value \\
\hline GBII09 & DV270764 & AJ132212 & Gnetum gnemon mRNA for putative MADS domain transcription factor & 85 & $4 e-17$ \\
\hline GBII10 & DV270765 & AAM66942 & Arabidopsis thaliana lipid transfer protein & 67 & $8 e-27$ \\
\hline GBII25 & DV270766 & CAA90628 & A. thaliana mRNA for sugar transport & 56 & $2 \mathrm{e}-12$ \\
\hline GBII38 & DV270767 & CAA58318 & A. thaliana glutathione synthetase gene, complete cds & 49 & $8 \mathrm{e}-29$ \\
\hline GBII42 & DV270768 & AAK58858 & Lycopersicon esculentum EIL2 (EIL2) mRNA, complete cds & 59 & $2 e-24$ \\
\hline GBII49 & DV270769 & AAX96020 & Oryza sativa putative $\mathrm{ABC}$ transporter protein & 98 & $8 \mathrm{e}-32$ \\
\hline GBII52 & DV270770 & CAA08994 & A. thaliana mRNA for MAP3K alpha protein kinase & 71 & $1 e-23$ \\
\hline GBII54 & DV270771 & CAA39444 & Nicotiana plumbaginifolia mRNA for superoxide dismutase & 67 & $8 \mathrm{e}-16$ \\
\hline GBII57 & DV270772 & AAL29303 & O. sativa ethylene receptor-like protein 2 mRNA & 58 & $4 \mathrm{e}-25$ \\
\hline GBII62 & DV270773 & BAD94687 & A. thaliana mRNA dehydration-induced protein RD22 & 60 & $3 e-22$ \\
\hline GBII65 & DV270774 & CAA62824 & A. thaliana mRNA for receptor-like kinase & 75 & $9 e-21$ \\
\hline GBII75 & DV270775 & AAX96808 & O. sativa transmembrane amino acid transporter protein & 80 & $4 e-29$ \\
\hline GBII77 & DV270776 & AAT10594 & $O$ sativa alcohol dehydrogenase-like protein & 87 & $3 e-05$ \\
\hline GBII85 & DV270777 & AAB40608 & N. tabacum glutamate decarboxylase & 64 & $7 e-32$ \\
\hline GBII89 & DV270778 & M74191 & Medicago sativa environmental stress-induced protein mRNA & 92 & $6 e-53$ \\
\hline GBII97 & DV270779 & BN000662 & $O$ sativa putative peroxidase & 89 & 1e-36 \\
\hline
\end{tabular}


incompatible compared with the compatible interactions, as verified by Northern blot analysis (Fig. 2). Some of those genes were found to be very strongly induced as early as 2 days postinoculation. Based on their expression profiles, four genes were chosen for functional analysis. Each of them was found to be quickly and highly induced in the incompatible interaction on N. megalosiphon, while no induction was observed in the compatible interaction on $N$. tabacum (Fig. 2). These genes comprised LTP (GBII10), GSHS (GBII38), EIL2 (GBII42), and GD (GBII85). VIGS analysis for these four candidates demonstrated that a knockdown of the glutathione synthetase gene and the EIL2 transcription factor gene in N. megalosiphon compromised disease resistance against $P$. hyoscyami. This demonstrates that both components are required for $P$. hyoscyami defense, and since neither of them is activated in the susceptible $N$. tabacum genotype, they could provide the basis for the disease-resistant phenotype of $N$. megalosiphon.

Clone GBII10 was found to display homology to plant lipid transfer proteins (LTP), small secreted cysteine-rich lipid-binding proteins. Until now, the precise biological roles of LTP re- main unclear, but they have been suggested to play a role in somatic embryogenesis, the formation of protective surface layers, and in defense against pathogens (Blein et al. 2002). VIGS of this lipid transfer protein in $N$. megalosiphon did not lead to noticeable changes in $P$. hyoscyami resistance.

Remarkably, two out of the 16 clones that were selected represent genes that are involved in ethylene signaling. Clone GBII57 represents a protein with significant homology (89\%) to an ethylene receptor-like protein from Oryza sativa, whereas

Table 2. Silencing efficiency in Nicotiana megalosiphon plants $^{\mathrm{a}}$

\begin{tabular}{lccc}
\hline Clones evaluated & Number of plants & Silenced & Nonsilenced \\
\hline pTV:GBII10 & 30 & 11 & 19 \\
pTV:GBII38 & 30 & 12 & 18 \\
pTV:GBII42 & 30 & 14 & 16 \\
pTV:GBII85 & 30 & 10 & 20 \\
pTV:PDS & 30 & 15 & 15 \\
\hline
\end{tabular}

${ }^{a}$ Efficiency upon virus-induced gene silencing treatment and as determined by Northern blot analysis.

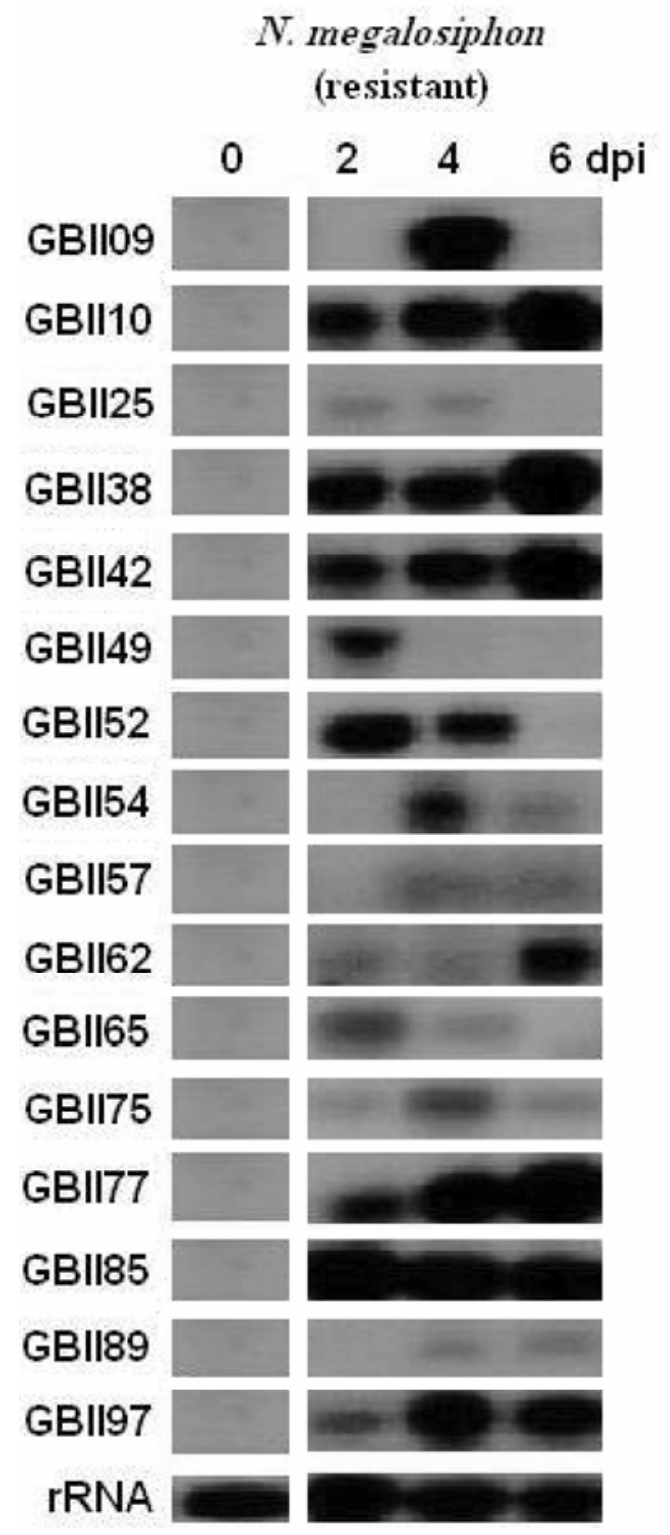

\section{N. tabacum cv. 'Sumatra' (susceptible)}

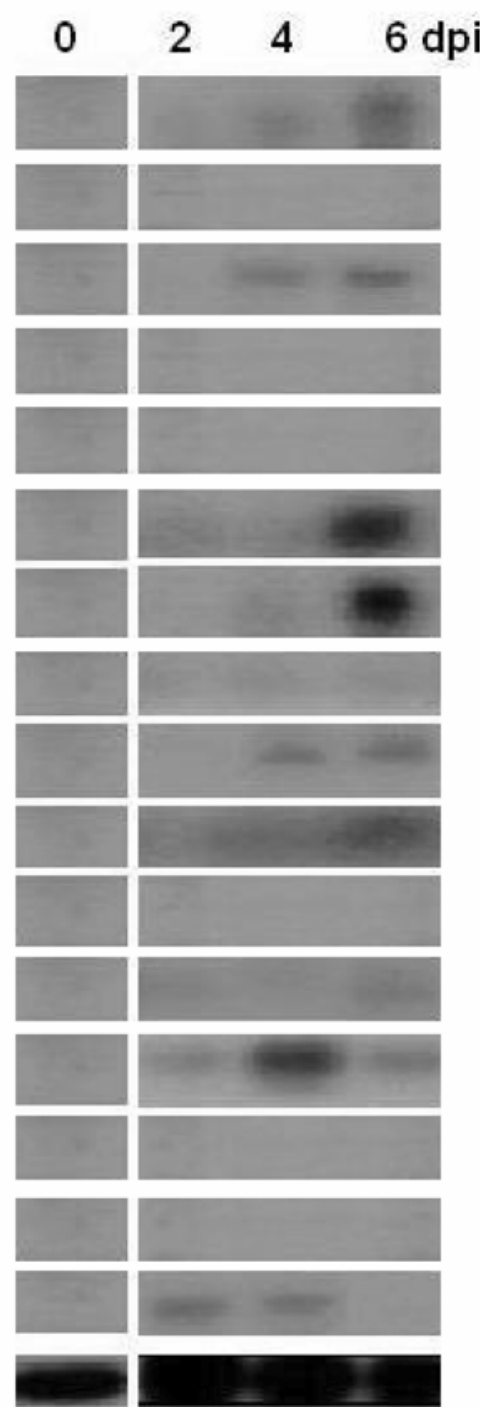

Fig. 2. Northern blot analysis of 16 selected cDNA clones to show the typical expression pattern in resistant (Nicotiana megalosiphon) and susceptible ( $N$. tabacum) plants upon infection. Six-week-old plants were inoculated with Peronospora hyoscyami at a concentration of $5 \times 10^{3}$ spores per milliliter. RNA was isolated at indicated times, and $10 \mu \mathrm{g}$ of RNA was separated on a denaturing agarose gel. The RNA blots were hybridized with the cDNA clones indicated at the left. 
clone GBII42 shares homology with a transcription factor gene (EIL2) belonging to the ethylene insensitive3 (EIN3)-like family (Rieu et al. 2003; Tieman et al. 2001). Ethylene is a gaseous plant hormone that affects a myriad of developmental processes (Guo and Ecker 2004) but also responsiveness to pathogen attack (Knoester et al. 1998; Thomma et al. 1999). In Arabidopsis, ethylene is perceived by a family of membrane-associated receptors. Genetic and biochemical studies have revealed that the ethylene receptors function as negative regulators of ethylene responses and that ethylene binding inactivates them (Guo and Ecker 2004). Subsequently, the Arabidopsis EIN3 and EIN3-like proteins bind in a sequence-specific manner to the primary ethylene-response element of the ethylene response factor $1(E R F 1)$ gene. $E R F 1$, in turn, directly activates transcription of a variety of ethylene-responsive $P R$ genes. Overexpression of EIN3 or EIL1 in wild-type Arabidopsis plants resulted in a constitutive ethylene phenotype and increased ERF1 expression. These results indicate that EIN3 is a transcription factor that acts as a positive regulator of the ethylene signal-transduction pathway (Chao et al. 1997; Solano et al. 1998), and apparently, EIN3 regulates expression of ethyleneresponsive genes by controlling levels of other transcription factors. In Arabidopsis and tomato, the EIL2 transcription factor has been demonstrated to function without transcriptional activation and thus independent of EIN3. Remarkably, we found that the EIL2 homolog is induced by ethylene (Fig. 3), but it is unknown if and how EIN3 is involved.

The observation that VIGS of the EIL2 transcription factor gene compromises $P$. hyoscyami resistance in $N$. megalosiphon indicates the importance of ethylene signaling in defense against this pathogen. Also, in a previous study, ethylene has been implicated in tobacco resistance against $P$. hyoscyami (Geraats et al. 2003). Transgenic tobacco plants expressing the mutant etrl-1 gene from Arabidopsis thaliana were found to be insensitive to ethylene and developed significantly less $P$. hyoscyami sporulation than control plants. Thus, ethylene insensitivity was found to result in increased resistance to this oomyceteous pathogen.

In addition, it was found that VIGS using the clone that displayed homology to an Arabidopsis thaliana glutathione synthetase gene (GBII38) also compromised $P$. hyoscyami resistance in $N$. megalosiphon. Glutathione is the most abundant low-molecular weight thiol in plants and is proposed to be in-
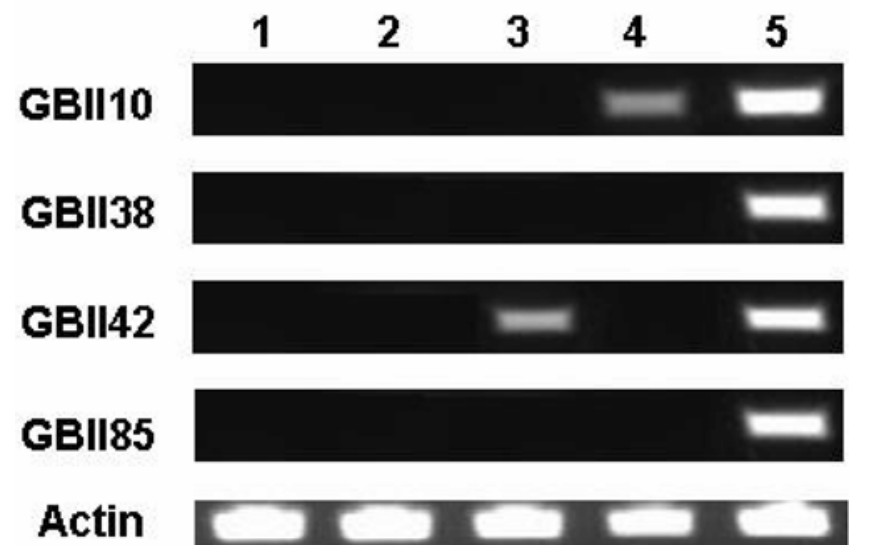

Fig. 3. Inducibility of pathogen-inducible Nicotiana megalosiphon genes by plant defense signaling molecules. Expression of a lipid transfer protein gene (LTP, GBII10), a glutathione synthetase gene (GSHS, GBII38), an EIL2 transcription factor gene (EIL2, GBII42), and a glutamate decarboxylase gene ( $G D$, GBII85) in $N$. megalosiphon plants treated with water (1), salicylic acid (2), ethylene (3), jasmonic acid (4), or Peronospora hyoscyami (5). In all cases samples, were taken 2 days posttreatment, and expression was monitored by reverse transcription-polymerase chain reaction. volved in plant antioxidant defense, in cellular detoxification mechanisms, in biotic or abiotic stress resistance, and in transport and storage of sulphur (May et al. 1998; Noctor et al. 2002). Its biosynthesis from its constituent amino acids is a well-characterized two-step ATP-dependent process that is similar in plants, animals, and microorganisms (Creissen et al. 1999). Glutathione synthetase catalyzes the last step of the biosynthesis, namely the ATP-dependent formation of glutathione from $\gamma$-glutamylcysteine and glycine (May et al. 1998; Noctor et al. 2002). Glutathione has been shown to be involved in plant-microbe interactions (Frendo et al. 2005; Vanacker et al. 2000) as well as in the induction of defense-related genes (Wingate et al. 1988). During the hypersensitive response (HR) to pathogens, plants rapidly produce and accumulate reactive oxygen species (ROS) and drastic increases in the pool of glutathione occur in cells surrounding the place of pathogen attack (Vanacker et al. 2000). It is thought that this increase in glutathione has two functions: i) to prevent excessive damage caused by ROS through its function as antioxidant (Foyer et al. 1997), and ii) to play a role as secondary messenger in defense responses (May et al. 1998; Noctor et al. 2002). Nevertheless, the exact role of glutathione as messenger remains obscure. Our experiments now demonstrate that the activity of a glutathione synthetase is required to obtain resistance in tobacco against $P$. hyoscyami.

Blue mold resistance in Nicotiana species varies from susceptible to immune (Clayton 1945). N. exigua has been shown to develop a HR-like reaction upon $P$. hyoscyami infection (Berry and McKean 1985). However, the genetic and mechanistic basis of this $N$. exigua response is unknown. More recently, Heist and associates (2004) presented evidence that the $N$. obtusifolia response is also a HR governed by a single, partially dominant gene. Although no genetic or microscopic evidence is presented, our data suggest that a HR is involved also in N. megalosiphon.

Most of the genes identified here are reported for the first time to be involved in the defense response of tobacco to blue
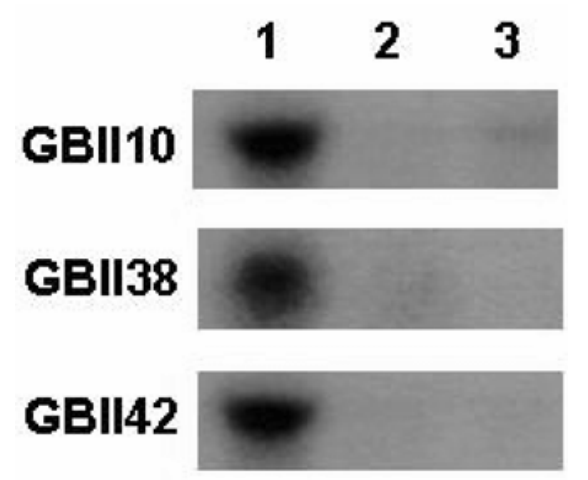

\section{GBII85}

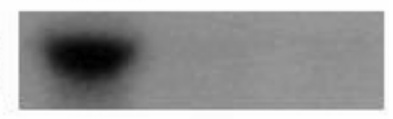

rRNA

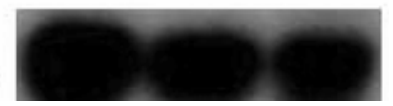

Fig. 4. Virus-induced gene silencing of candidate genes in Nicotiana megalosiphon. Transcript accumulation of a lipid transfer protein gene (LTP, GBII10), a glutathione synthetase a gene (GSHS, GBII38), an EIL2 transcription factor gene (EIL2, GBII42), and a glutamate decarboxylase gene (GD, GBII85) in leaf material from nonsilenced $N$. megalosiphon (1), silenced N. megalosiphon (2), and N. tabacum cv. Sumatra (3), 1 week postinoculation with Peronospora hyoscyami, analyzed by Northern blot hybridization. 
mold in the incompatible interaction. The genes that have been identified as crucial for an efficient defense against tobacco blue mold can be exploited in strategies to develop durable resistance in cultivated tobacco plants through either markerassisted breeding or biotechnological approaches. Since most,

\section{GBII10}

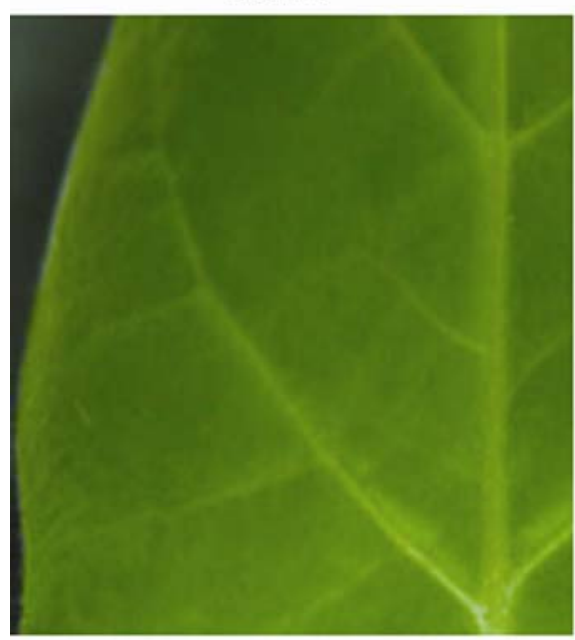

GB1142

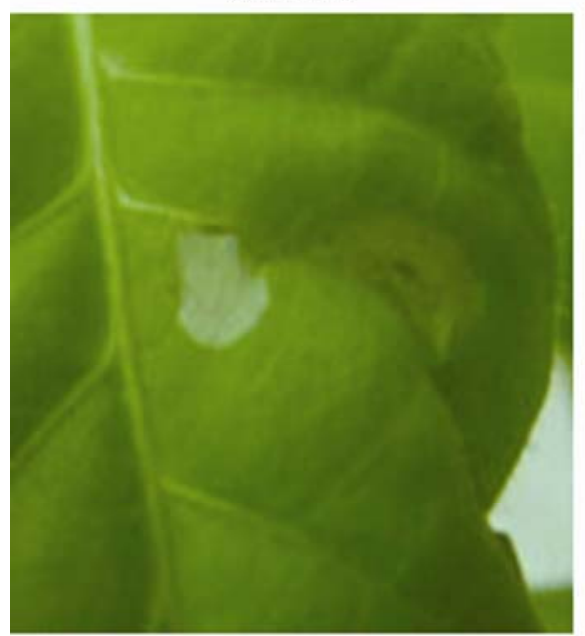

nonsilenced $N$. magalosiphon

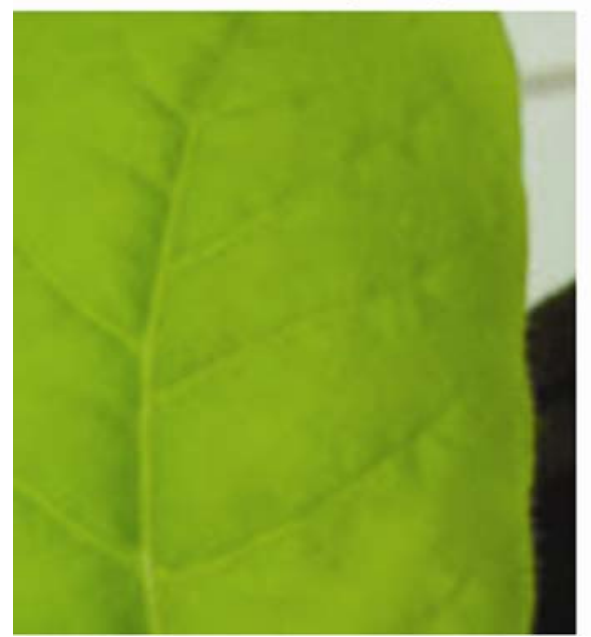

if not all, tobacco varieties are likely to have functional EIL2 and GSHS genes, it can be anticipated that their regulation determines the level of resistance. This implies that exploitation of these genes could be a challenge to be tackled in future studies.

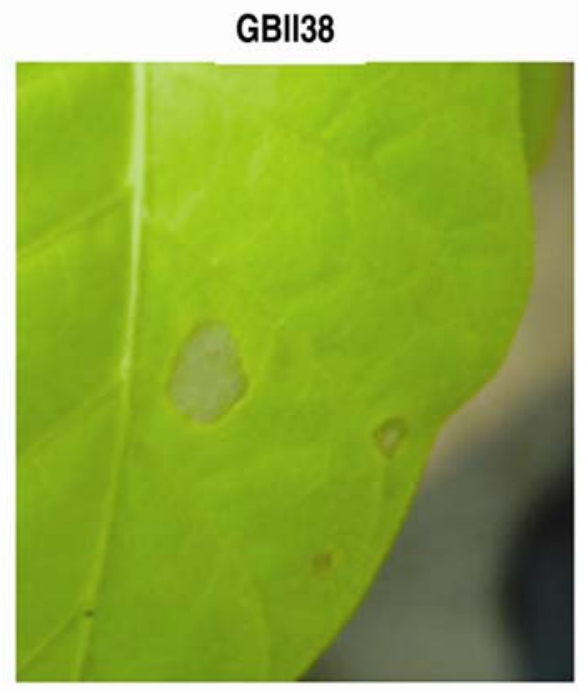

GBII85
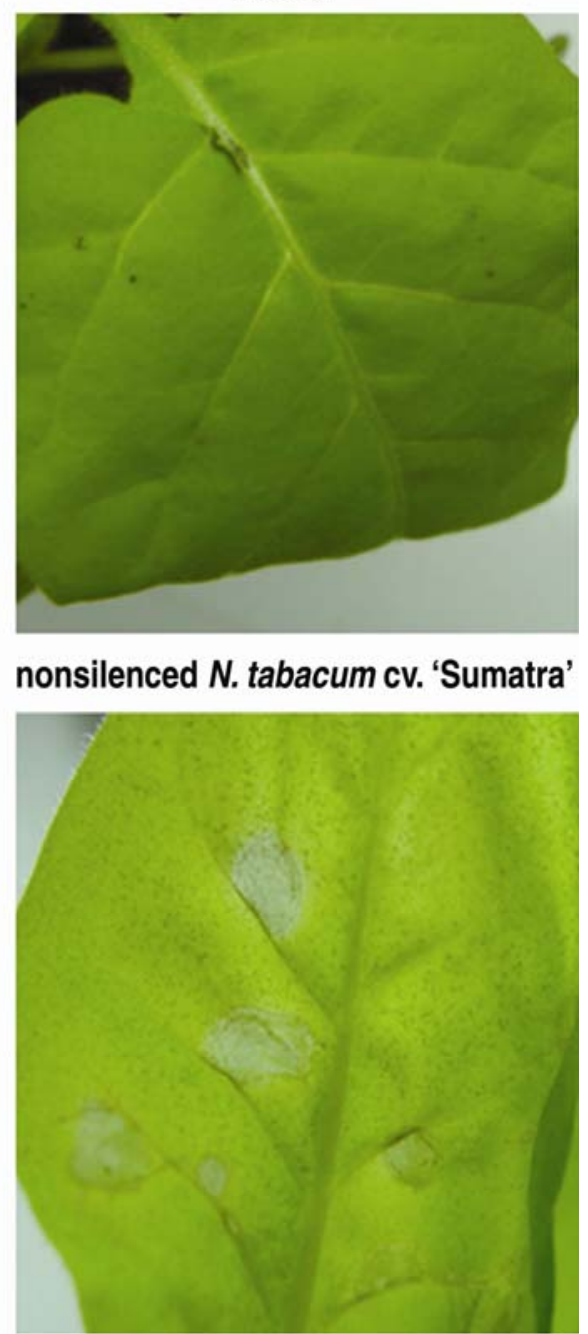

Fig. 5. Response of Nicotiana megalosiphon to infection with Peronospora hyoscyami upon virus-induced gene silencing (VIGS) of candidate genes. GBII10: VIGS of a lipid transfer protein gene (LTP); GBII38: VIGS of a glutathione synthetase gene (GSHS); GBII42: VIGS of an EIL2 transcription factor gene (EIL2); and GBII85: VIGS of a glutamate decarboxylase gene (GD). Nonsilenced N. megalosiphon and N. tabacum cv. 'Sumatra' plants are included as control. Pictures were taken 1 week postinoculation with $P$. hyoscyami. 


\section{MATERIALS AND METHODS}

\section{Inoculation of tobacco with $P$. hyoscyami.}

The susceptible tobacco species N. tabacum cv. Sumatra and the resistant wild-tobacco genotype $N$. megalosiphon (seed provided by the Tobacco Research Institute, Havana, Cuba) were grown from seed in 6-inch pots containing black turf and rice husk (4:1) and were maintained in growth chambers at $23^{\circ} \mathrm{C}$ (Pérez et al. 2000). A field isolate of $P$. hyoscyami f. sp. tabacina (provided by the Cuban Research Institute of Plant Health, Havana, Cuba) was used for all inoculations throughout this study. This isolate was collected from a tobacco field in Havana and was experimentally determined to be sensitive to the fungicide metalaxyl (Muiño et al. 1997). The pathogen was propagated on 6- to 12-week-old N. tabacum cv. Sumatra plants grown in growth chambers at $23^{\circ} \mathrm{C}$. Infected plants were maintained by infiltrating pathogen spores into the leaves of $N$. tabacum cv. Sumatra. To this end, the pathogen was induced to sporulate by placing infected leaves in a moistened, black plastic bag overnight. Bags were moistened by spraying a fine water mist inside prior to insertion of infected leaves. Sporangia were harvested the following day by lightly scraping the surface of sporulating lesions with a sterile wooden applicator stick (Fisher Scientific, Pittsburgh, PA, U.S.A.) and swirling the sample in a $1.5-\mathrm{ml}$ microcentrifuge tube containing $1 \mathrm{ml}$ of sterile distilled water. New 6-week-old N. tabacum cv. Sumatra and $N$. megalosiphon plants were inoculated by placing several 10$\mu \mathrm{l}$ droplets of a $5 \times 10^{3}$ spores per $\mathrm{ml}$ (determined with a haemacytometer) suspension onto leaf panels. The plants were then placed in moistened, black plastic bags overnight to promote infection. Mock-inoculated N. tabacum cv. Sumatra and $N$. megalosiphon plants were used as controls.

\section{Suppression subtractive library construction.}

Total RNA was extracted from infected as well as noninfected N. megalosiphon leaves using the spin or vacuum (SV) total RNA isolation system (Promega, Madison, WI, U.S.A.). Poly (A)+ RNA was isolated using the Dynabeads mRNA purification kit (Dynal A.S., Oslo, Norway), according to the manufacturer's instructions. Finally, double-stranded cDNA was synthesized (cDNA Synthesis System; Promega).

A subtracted cDNA library was constructed by subtractive hybridization using the PCR-Select subtractive hybridization kit (Clontech, Palo Alto, CA, U.S.A.). Basically, a cDNA pool prepared from $N$. megalosiphon leaves inoculated with $P$. hyoscyami f. sp. tabacina and harvested at 2, 4, and 6 days postinoculation was used as the 'tester' sample, and that of a mock inoculated plant sample was used as the 'driver' for the forward subtraction that was performed to isolate cDNAs corresponding to genes whose expression was up-regulated upon pathogen inoculation.

The subtracted library was cloned into the pGEM-T Easy vector (Promega) according to manufacturer's instructions. Colonies were picked and grown in 96-well microtiter plates in Luria-Bertani medium containing $100 \mathrm{mg}$ of ampicillin per liter. All clones were PCR-amplified using the nested primers 1 and $2 \mathrm{R}$ (Clontech) to check the presence and size of the individual inserts. In addition, all PCR products were spotted on nylon filters. These membranes were hybridized under stringent conditions with equivalent amounts of ${ }^{32} \mathrm{P}$ labeled probes generated from driver, unsubtracted, and subtracted cDNA pools.

\section{DNA sequencing and sequence data analysis.}

DNA sequencing was performed using an automated ABI model 377 DNA sequencer (Applied Biosystems, Warrington, U.K.). The procedures were performed according to the manu- facturer's instructions. The M13 forward and reverse primers were used to generate sequences for all cDNAs isolated (Perkin Elmer ABI PRISM Dye Terminator Cycle sequencing kit; Perkin Elmer, Boston), and the sequences were submitted to GenBank (accession numbers DV270764 to DV270779 and DV668283 to DV668448). Analyses for cDNA sequence similarity to database sequences were conducted by comparison with the nonredundant protein databases using BLASTX and BLASTN homology searches (Altschul et al. 1997). E-value scores below $10^{-5}$ were considered as significant and were used to indicate homology between tobacco sequences and database sequences.

\section{Northern-blot analysis.}

Poly (A)+ RNA from N. megalosiphon and N. tabacum cv. Sumatra $(0,2,4$, and 6 days postinoculation) were size-fractionated on a $1.2 \%$ agarose and $0.4 \mathrm{M}$ formaldehyde RNA gel and were transferred to Hybond $\mathrm{N}+$ nylon membrane (Amersham Pharmacia, Buckinghamshire, U.K.). For clones that appeared to have database homologs with a low $E$-value, probes were generated from PCR-amplified fragments, using the ReadyPrime random primed DNA labeling kit (Amersham Pharmacia) with $\left[{ }^{32} \mathrm{P}\right]$ (ICN Biomedicals, Irvine, CA, U.S.A.). Blots were hybridized and washed according to standard procedures (Sambrook et al. 1989).

\section{Analysis of transcript levels by RT-PCR.}

Total RNA was extracted from N. megalosiphon leaves treated with water, ethylene (ethephon $1 \mathrm{mM}$ ), salicylic acid (2 $\mathrm{mM})$, jasmonic acid $(0.5 \mathrm{mM})$, and $P$. hyoscyami f. sp. tabacina 2 days posttreatment. The SV total RNA isolation system (Promega) was used for RNA isolation. Poly(A)+ RNA was isolated using the Dynabeads mRNA purification kit (Dynal A.S.), according to the manufacturer's instructions. Primers that amplified GBII10 (forward, CGTATCTCGAGCATGCTGC; reverse, GTGGTCGCTGCGATGCTAGC), GBII38 (forward, ACTAGTCTCAGCTACCTCAGC; reverse, CATGCAGTAGCTAGCTATGC), GBII42 (forward, AGCACTCAGATCGCACTGC; reverse, GCTACGTGACGTCATACTCG), and GBII85 (forward, CTGCAGTGGAGTGCTACGC; reverse, CGCACGACTAGTTGCAGAC) cDNA clones were used in the RT-PCR assay using the Access RT-PCR system (Promega). Five plants were used for each treatment.

\section{VIGS assay.}

For VIGS analysis in P. hyoscyami-resistant $N$. megalosiphon plants, TRV vectors were used (Ratcliff et al. 2001). The PDS gene (used as a control to monitor silencing efficiency in $N$. megalosiphon), GBII10, GBII38, GBII42, and GBII85 cDNA fragments were cloned using the SmaI sites of pTV00 to form pTV:PDS, pTV:GBII10, pTV:GBII38, pTV:GBII42, and pTV:GBII85, respectively. The infection of N. megalosiphon

Table 3. Characterization of disease severity of Peronospora hyoscyami ${ }^{\mathrm{a}}$

\begin{tabular}{lccc}
\hline & \multicolumn{3}{c}{ Number of lesions per leaf } \\
\cline { 2 - 4 } $\begin{array}{l}\text { Clones } \\
\text { evaluated }\end{array}$ & $\begin{array}{c}\text { Nonsilenced } \\
\text { N. megalosiphon }\end{array}$ & $\begin{array}{c}\text { Silenced } \\
\text { N. megalosiphon }\end{array}$ & $\begin{array}{c}\boldsymbol{N} \text {. tabacum } \\
\text { cv. Sumatra }\end{array}$ \\
\hline GBII10 & 0 & 0 & $10.4 \pm 2$ \\
GBII38 & 0 & $3.2 \pm 1$ & $11.3 \pm 1$ \\
GBII42 & 0 & $2.4 \pm 2$ & $10.5 \pm 2$ \\
GBII85 & 0 & 0 & $11.8 \pm 1$ \\
\hline
\end{tabular}

${ }^{a}$ Severity in Nicotiana megalosiphon upon virus-induced gene silencing treatment for four candidate genes 1 week postinoculation, as mean number of lesions per leaf. Values are the mean of 10 replicates, and \pm represents standard deviation. As control, the susceptible N. tabacum cv. Sumatra is included. 
with TRV was carried out using a total of 30 plants per construct, using the protocol as described (Ratcliff et al. 2001). After TRV inoculation, transcript accumulation was monitored by Northern-blot analysis using the GBII10, GBII38, GBII42, and GBII 85 cDNA clones as probes according to the above described procedure. Ten days postinoculation with the TRV constructs, the plants were inoculated with $P$. hyoscyami f. sp. tabacina, and subsequently, the development of symptoms was monitored.

\section{ACKNOWLEDGMENTS}

We are grateful to the Tobacco Research Institute for providing the tobacco seeds for the experiments. B. P. H. J. Thomma is supported by a VENI grant of the Research Council for Earth and Life sciences (ALW) of the Netherlands Organization for Scientific Research (NWO)

\section{LITERATURE CITED}

Altschul, S. F., Madden, T. L., Schaffer, A. A., Zhang, J. H., Zhang, Z., Miller, W., and Lipman, D. J. 1997. Gapped BLAST and PSIBLAST: A new generation of protein database search programs. Nucleic Acids Res. 25:3389-3402.

Avdiushko, S. A., Ye, X. S., Hildebrand, D. F., and Kuc, J. 1993. Induction of lipoxygenase activity in immunized cucumber plants. Physiol. Mol. Plant Pathol. 42:83-95.

Berry J. W., and McKean, W. E. 1985. Development of Peronospora hyoscyami f. sp. tabacina in the resistant host Nicotiana exigua. Can. J. Plant Pathol. 7:262-269.

Blein, J. P., Coutos-Thevenot, P., Marion, D., and Ponchet, M. 2002. From elicitins to lipid-transfer proteins: A new insight in cell signaling involved in plant defence mechanisms. Trends Plant Sci. 7:293-296.

Chao, Q., Rothenberg, M., Solano, R., Roman, G., Terzaghi, W., and Ecker, J. 1997. Activation of the ethylene gas response pathway in Arabidopsis by the nuclear protein ETHYLENE INSENSITIVE 3 and related proteins. Cell 89:1133-1144.

Clayton, E. 1945. Resistance of tobacco to blue mold (Peronospora tabacina). J. Agr. Res. 70:79-87

Creissen, G., Firmin, J., Fryer, M., Kular, B., Leyland, N., Reynolds, H., Pastori, G., Wellburn, F., Baker, N., Wellburn, A., and Mullineaux, P. 1999. Elevated glutathione biosynthetic capacity in the chloroplasts of transgenic tobacco plants paradoxically causes increased oxidative stress. Plant Cell 11:1277-1291.

Espino, E., and Rey, X. 1987. Nuevas variedades de tabaco negro para cultivo bajo tela resistentes al moho azul (Peronospora tabacina). Agrotecnia Cuba 19:247-260.

Espino, E., Rey, X., and García, V. 1997. Habana 92 y Habana 2000: Dos nuevas variedades de tabaco negro resistentes al moho azul Peronospora tabacina. Rev. Cubana Agr. 1:15-24.

Foyer, C. H., Lopez-Delgado, H., Dat, J. F., and Scott, I. M. 1997. Hydrogen peroxide-and glutathione-associated mechanisms of acclimatory stress tolerance and signaling. Plant Physiol. 100:241-254.

Fray, R. G., and Grierson, D. 1993. Identification and genetic analysis of normal and mutant phytoene synthase genes of tomato by sequencing, complementation, and co-suppression. Plant Mol. Biol. 22:589-602.

Frendo, P., Harrison, J., Norman, C., Hernández-Jiménez, M. J., Van de Sype, G., Gilabert, A., and Puppo, A. 2005. Glutathione and homoglutathione play a critical role in the nodulation process of Medicago truncatula. Mol. Plant-Microbe Interact. 18:254-259.

Funnell, D. L., Lawrenceb, C. B., Pedersenc, J. F., and Schardl, C. L. 2004. Expression of the tobacco $\beta-1,3$-glucanase gene, $P R$ - $2 d$, following induction of SAR with Peronospora tabacina. Physiol. Mol. Plant Pathol. 65:285-296.

Geraats, B. P. J., Bakker, P. A. H. M., Lawrence, C. B., Achuo, E. A., Höfte, M., and van Loon, L. C. 2003. Ethylene-insensitive tobacco shows differentially altered susceptibility to different pathogens. Phytopathology 93:813-821.

Guo, H., and Ecker, J. R. 2004. The ethylene signaling pathway: New insights. Curr. Opin. Plant Biol. 7:40-49.

Heist, E. P., Nesmith, W. C., and Schardl, C. L. 2002. Interactions of Peronospora tabacina with roots of Nicotiana spp. in gnotobiotic associations. Phytopathology 92:400-405.

Heist, E. P., Zaitlin, D., Funnell, D. L., Nesmith, W. C., and Schardl, C. L.
2004. Necrotic lesion resistance induced by Peronospora tabacina on leaves of Nicotiana obtusifolia. Phytopathology 94:1178-1188.

Johnson, G. I. 1989. Peronospora hyoscyami de Bary: Taxonomic History, Strains and Host Range. Pages 1-8 in: Blue Mold of Tobacco. W. E. McKeen. American Phytopathological Society Press, St. Paul, U.S.A.

Knoester, M., van Loon, L. C., van den Heuvel, J., Hennig, J., Bol, J. F., and Linthorst, H. J. M. 1998. Ethylene-insensitive tobacco lacks nonhost resistance against soil-borne fungi. Proc. Natl. Acad. Sci. U.S.A. 95:1933-1937.

Kuc, J. 1982. Induced immunity to plant disease. Bioscience 32:854-860.

Lucas, G. B. 1975. Pages 621 in: Diseases of Tobacco, 3rd ed. Biological Consulting Associates, Raleigh, NC, U.S.A.

May, M. J., Vernoux, T., Sánchez-Fernández, R., Van Montagu, M., and Inzé, D. 1998. Evidence for posttranscriptional activation of $\gamma$-glutamylcysteine synthetase during plant stress responses. Proc. Natl. Acad. Sci. U.S.A. 95:12049-12054

Muiño, B. L., Espino, M., Rodríguez, F., Almandoz, J., Peñalver, L., Ruiz, M. A., and Benitez, M. E. 1997. Efectividad del dimethomorph sobre Peronospora tabacina Adam (moho azul) en el cultivo del tabaco. Sanidad Vegetal 2:154-155.

Noctor, G., Gomez, L., Vanacker, H., and Foyer, C. H. 2002. Interactions between biosynthesis, compartmentation and transport in the control of glutathione homeostasis and signaling. J. Exp. Bot. 53:1283-1304.

Pan, S. Q., Ye, X. S., and Kuc, J. 1991. Association of beta-1,3,-glucanase activity and isoform pattern with systemic resistance to blue mould in tobacco induced by stem injection with Peronospora tabacina or leaf inoculation with Tobacco mosaic virus. Physiol. Mol. Plant. Pathol. 39:25-39.

Pérez, E., Fernández, A., and Andino, V. 2000. Page 50 in: Tecnología Para la Eliminación del Bromuro de Metilo. Instituto de Sanidad Vegetal, MINAGRI, Ciudad de la Habana, Cuba.

Ratcliff, F., Martin-Hernandez, A. M., and Baulcombe, D. C. 2001. Tobacco rattle virus as a vector for analysis of gene functions by silencing. Plant J. 25:237-245.

Reuveni, M., Nesmith, W. C., and Siegel, M. R. 1986. Symptom development and disease severity in Nicotiana tabacum and $N$. repanda caused by Peronospora tabacina. Plant Dis. 70:727-729.

Rieu, I., Mariani, C., and Weterings, K. 2003. Expression analysis of five tobacco EIN3 family members in relation to tissue-specific ethylene responses. J. Exp. Bot. 54:2239-2244.

Sambrook, J., Fritsch, E. F., and Maniatis, T. 1989. Molecular Cloning: A Laboratory Manual. Cold Spring Harbor Laboratory Press, Cold Spring Harbor, NY, U.S.A

Solano, R., Stepanova, A., Chao, Q., and Ecker, J. R. 1998. Nuclear events in ethylene signaling: A transcriptional cascade mediated by ETHYLENE-INSENSITIVE3 and ETHYLENE RESPONSE- FACTOR1. Genes Dev. 12:3703-3714.

Thomma, B. P. H. J., Eggermont, K., Tierens, K. F. M.-J., and Broekaert, W. F. 1999. Requirement of functional EIN2 (ethylene insensitive 2) gene for efficient resistance of Arabidopsis thaliana to infection by $B o-$ trytis cinerea. Plant Physiol. 121:1093-1101.

Thomma, B. P. H. J., Penninckx, I. A. M. A., Broekaert, W. F., and Cammue, B. P. A. 2001. The complexity of disease signaling in Arabidopsis. Curr. Opin. Immunol. 13:63-68.

Tieman, D. M., Ciardi, J. A., Taylor, M. G., and Klee, H. J. 2001. Members of the tomato LeEIL (EIN3-like) gene family are functionally redundant and regulate ethylene responses throughout plant development. Plant J. 26:47-58

Vanacker, H., Carver, T. L. W., and Foyer, C. H. 2000. Early $\mathrm{H}_{2} \mathrm{O}_{2}$ accumulation in mesophyll cells leads to induction of glutathione during the hyper-sensitive response in the barley-powdery mildew interaction. Plant Physiol. 123:1289-1300.

Wingate, V. P. M., Lawton, M. A., and Lamb, C. J. 1988. Glutathione causes a massive and selective induction of plant defense genes. Plant Physiol. 31:205-211.

Wolf, F. A., Dixon, L. F., McLean, R., and Darkis, F. R. 1934. Downy mildew of tobacco. Phytopathology 24:337-363.

Ye, X. S., Pan, S. Q., and Kuc, J. 1989. Pathogenesis-related proteins and systemic resistance to blue mould and tobacco mosaic virus induced by tobacco mosaic virus, Peronospora tabacina and aspirin. Physiol. Mol. Plant Pathol. 35:161-175

Ye, X. S., Pan, S. Q., and Kuc, J. 1990. Association of pathogenesisrelated proteins and activities of peroxidase, beta-1,3-glucanase and chitinase with systemic induced resistance to blue mould of tobacco but not to systemic tobacco mosaic virus. Physiol. Mol. Plant Pathol. 36:523-531. 